\title{
Formation and Study of Nanostructured M-Monolayers and LS-Films of Triphenylcorrole
}

\author{
Thao T. Vu, ${ }^{a}$ Larissa A. Maiorova, ${ }^{a}$ Dmitrii B. Berezin, ${ }^{a}$ and Oskar I. Koifman ${ }^{\mathrm{a}, \mathrm{b}}$ \\ Dedicated to Academician of Russian Academy of Sciences Oleg Sinyashin \\ on the occasion of his birthday
}

${ }^{a}$ Research Institute of Macroheterocycles, Ivanovo State University of Chemistry and Technology, 153000 Ivanovo, Russian Federation

${ }^{\mathrm{b}}$ G.A. Krestov Institute of Solution Chemistry, Russian Academy of Sciences, 153045 Ivanovo, Russian Federation

${ }^{\circledR}$ Corresponding authorE-mail: valkovala@mail.ru

\begin{abstract}
An experimental and theoretical study of 5,10,15-triphenylcorrole $\left(\mathrm{H}_{3}\left[(\mathrm{~ms}-\mathrm{Ph})_{3}\right.\right.$ Cor $]$ ) nano-structured floating layers (M-layers) was performed. The existence areas and characteristics of the structure and properties of stable monomolecular layers were determined. Main dependencies of the M-monolayer on the initial surface coverage degree were identified - the sizes of the nanoaggregate, aggregation number, surface area per molecule in a nanoaggregate, etc. A quantitative model of a monolayer with water and dry M-nanoaggregates was constructed. $\mathrm{H}_{3}\left[(\mathrm{~ms}-\mathrm{Ph})_{3} \mathrm{Cor}\right]$ thin films on solid substrates were obtained using the Langmuir-Schaefer (LS) technique, and their spectral characteristics were explored.
\end{abstract}

Keywords: Floating monolayers, 2D nanostructures, M-nanoaggregates, model of M-monolayer, LS-films, corrole.

\section{Формирование и исследование наноструктурированных

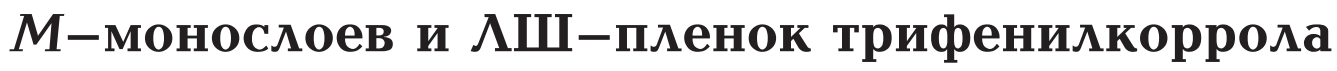

\author{
Тхао Т. Ву, ${ }^{a}$ ᄉ. А. Майорова, ${ }^{a}$ А. Б. Березин, ${ }^{a}$ О. И. Койфмман ${ }^{\mathrm{a}, \mathrm{b}}$ \\ Посвящается акаgемику РАН Олегу Герольgовичу Синяшину по случаю его юбилея
}

${ }^{a}$ НИИ макрогетерочиклических соединений, Ивановский государственный химико-технологический университет, 153000 Иваново, Россия

' Институт химии растворов им. Г.А. Крестова РАН, 153045 Иваново, Россия

${ }^{\circledR}$ E-mail: valkovala@mail.ru

\begin{abstract}
Выполнено экспериментальное и теоретическое исследование наноструктурированных плавающих слоев (М-слоев) тетрапиррольного макроциклического соединения - 5,10,15-трифенилкоррола $\left(\mathrm{H}_{3}\left[(\mathrm{~ms}-\mathrm{Ph})_{3} \mathrm{Cor}\right]\right)$. Определень области существования и характеристики структуры и свойств стабильных мономолекулярных слоев. Установлены зависимости основных характеристик М-монослоя - размера наноагрегата, агрегациионного числа, площчади, приходящеейя на молекулу в наноагрегате, и др. от исходной степени покрытия поверхности. Построена количественная модель монослоя с водными и сухими М-наноагрегатами. Методом Ленгмюра-Шефера (ЛШ) получены тонкие пленки $\mathrm{H}_{3}\left[(\mathrm{~ms}-\mathrm{Ph})_{3} \mathrm{Cor}\right]$ на твердых подложках и изучень их спектральные характеристики.
\end{abstract}

Ключевые слова: Плавающие монослои, 2D наноструктуры, М-наноагрегаты, модель М-монослоя, ЛШ-пленки, коррол. 


\section{Introduction}

Corroles are tetrapyrrolic macrocyclic porphyrin-like compounds which contain a pyrrole-pyrrole direct coupling and have a carbon skeleton, resembling the $B_{12}$ vitamin. The peculiarities of the electronic structure of corroles $\left(\mathrm{H}_{3} \mathrm{Ph}_{3} \mathrm{Cor}\right)$ (Figure1) and their metal complexes (MCor), morphological variety and unique photophysical and chemical properties have raised interest to them as potential catalyzers for redox processes, chemical sensors for small molecules, and active centers when producing nanomaterials for the area of medicine. ${ }^{[1,2]}$ When complexes are formed, the corroles, being non-innocent ligands, stabilize metal ions in unusual oxidation degrees, which cause the complexes to suffer slight reversible intramolecular redox transformations. [3-9] This property accounts for the compounds' high catalytic activity. ${ }^{[10]}$ One of today's emerging trends is focused on creation of thin-film organic materials, including based on corroles, ${ }^{[1-20]}$ especially those, where structural and functional units are represented by 2D and 3D nanoparticles. ${ }^{[21,22]}$ First supermolecules of macroheterocyclic compounds were obtained. ${ }^{[16-18]}$ Thin films of corroles can be obtained in different ways, including vacuum sublimation, solution casting, and Langmuir-Blodgett techniques (LB). The last one creates ultrathin (as fine as monomolecular) films, which have a desired shape and adjustable structure, with a large specific surface. Such corrole films can be used as potential components for electrode nanomaterials as well.

Properties of thin-film organic nanomaterials are determined by their structure, which depends on the structure of the floating layers when using the LB technique. Studies of Langmuir layers of organic compounds with complex molecular structure have shown, among other things that the compounds' behaviour within the layer depends on the volumetric concentration of the applied solution and the initial surface concentration of the compound under study. ${ }^{[23-25]}$ A technique to determine quantitative characteristics of a floating layer, the structural and functional units of which are represented by 2D nanoaggregates sized 5-20 $\mathrm{nm}$ (M-nanoaggregates) was developed and successfully used for describing floating layers of calamite mesogens, ${ }^{[26]}$ porphyrins, ${ }^{[27]}$ and phthalocyanines. ${ }^{[28-30]}$

The objectives of this study are to: explore features of 5,10,15-triphenylcorrole $\left(\mathrm{H}_{3}\left[(m s-\mathrm{Ph})_{3} \mathrm{Cor}\right]\right)$ floating layer formation under various initial surface coverage degrees; obtain stable M-monolayers with various structures of 2D nanoaggregates; determine characteristics of floating monolayers; construct a model of monolayers with water and dry M-nanoaggregates; obtain, by using the Langmuir Schaefer (LS) technique as well, $\mathrm{H}_{3}\left[(m s-\mathrm{Ph})_{3} \mathrm{Cor}\right]$ thin films on solid substrates and study them with UV-Vis spectroscopy.

\section{Experimental}

5,10,15-Triphenylcorrole was obtained using a technique, described earlier ${ }^{[31,32]}$ Its structure was confirmed by ${ }^{1} \mathrm{~N}$ NMR, IR and UV-Vis spectra. The floating layers were obtained by applying the $\mathrm{H}_{3}\left[(m s-\mathrm{Ph})_{3} \mathrm{Cor}\right]$ solution in methylene chloride $\left(C=6.9 \cdot 10^{-5} \mathrm{~mol} \cdot \mathrm{l}^{-1}\right)$ to the surface of bi-distilled water with microliter syringes $(1,10,20$, and $100 \mu 1$, "Hamilton", Sweden) at the temperature of $20 \pm 1{ }^{\circ} \mathrm{C}$. The layers were compressed at the speed of $2.3 \mathrm{~cm}^{2} \cdot \mathrm{min}^{-1} 15$ minutes after the solution had been applied to the water surface. Initial degrees of water surface coverage with corrole $\left(C_{\text {face }}\right)$ changed from $4 \%$ to $29 \%$. An"NT (MDT" unit (Zelenograd, Russia) was used for the experiment. The surface pressure was measured by using a Wilhelmy plate with an accuracy of $0.02 \mathrm{mN} \cdot \mathrm{m}^{-1}$. Error of measurement with respect to a surface area per molecule in the layer $(A)$ was $2 \%$. $A_{\text {mol }}$ values (surface area per molecule in an $M$-aggregate) and $n$ (aggregation number) were determined by approximation of $\mathrm{p} A$-p curve's portion with a linear function, by using the least squares technique (error $\pi A \leq 3 \%$ ). The Langmuir-Schaeffer (LS) films were obtained by transferring the floating layer to the quartz plate under conditions, shown on Figure 3 (point A). Electronic absorption spectra were registered on a UV/VIS Lambda 20 scanning spectrophotometer with $\pm 0.1 \mathrm{~nm}$ wavelength setting accuracy. The reproducibility of the wavelength setting was $\pm 0.05 \mathrm{~nm}$, the photometric accuracy being \pm 0.003 . The structure of the layers was analyzed by using quantitative analysis of compression isotherms of a nanostructured $M$-monolayer. ${ }^{[33-35]}$ The main characteristics of the floating layer were determined in the following manner: $\beta=k T / n$, where $\beta$ is the ordinate of the intersection point between the line, describing the isotherm's $\pi A-\pi$ region corresponding to the stable state of the layer, and the $\pi A$ axis; $A_{m o l}$ is the line's tilt. According to the model being used, $M$-aggregate has a shape of a circle with the surface area of $\mathrm{S}_{a g g r}=A_{m o l} \mathrm{n}\left(\mathrm{nm}^{2}\right)$ and the diameter of $D_{a g g r}=\sqrt{4 S_{a g g r / \pi}}(\mathrm{nm})$. The layer's compressibility in a stable state can be defined as

$B=\frac{A_{i}-A_{f}}{\left(\pi_{f}-\pi_{i}\right) \cdot A_{i}}(\mathrm{~m} / \mathrm{N})$, where $\pi_{i}$ and $\pi_{f}$ are the respective pressures at the start and at the end of the monolayer's stable state, with $A_{i}$ and $A_{f}$ being the abscissas of the start and the end of the linear portion of the $\pi$ - $A$-isotherm. The distance between the boundaries of the aggregates is the same on the average, and can be calculated from the relation:

$d_{i}=\sqrt{\frac{A_{i} \cdot n}{\pi}}-\sqrt{\frac{4 A_{\text {mol }} \cdot n}{\pi}}(\mathrm{nm})$. The average distance between the molecules along the surface of the water (face-on) in an $M_{\text {face }}{ }^{-}$ aggregate will be $r=\sqrt{\frac{4 A_{m o l}}{\pi}}-\sqrt{\frac{4 A_{p r o j}}{\pi}}(\mathrm{nm})$. Water coverage degrees at the initial point of the stable state can be defined as $c_{i \text {-face }}=A_{\text {proj-face }} / A_{i} 100 \%$ and $c_{i \text {-edge }}=A_{\text {proj-edge }} / A_{i} \cdot 100 \%$, where $A_{\text {proj-face }}$ and $A_{\text {proj-edge }}$ are surface areas of face-on and edge-on projections of molecule models. Within the linear portion on curve $\pi A-\pi$, the tilt of the molecules (which have an anisotropic shape) in the stack of a compact nonaqueous aggregate can be defined as $\psi=\arcsin \left(A_{\text {pack-edge }} / A_{\text {mol }}\right)$, where $A_{\text {pack-edge }}$ is the closest packed surface area. The content of water in $M$-aggregates (calculated per molecule) and between them at the initial point of the stable state can be calculated with $w_{i n-M}=A_{m o l}-A_{\text {proj }}$ and $w_{\text {inter }-M-i}=A_{i}-A_{\text {mol }}$ expressions respectively.

Geometric characteristics of the molecules and their closest packings were determined by constructing the corresponding molecular models (HyperChem 8.0.8, MM+ calculations). The surface areas of projections in case of face-on and edge-on positions of the molecules were found to be: $A_{\text {projface }}=1.6 \mathrm{~nm}^{2}$, $A_{\text {proj-1(edge) }}=0.8 \mathrm{~nm}^{2}, A_{\text {proj-2(edge) }}=1.0 \mathrm{~nm}^{2}$; with the surface areas of the described rectangles being $A_{\text {mod(face) }}=3.2 \mathrm{~nm}^{2}$ and $A_{\text {mod-l(ledge) }}=1.1 \mathrm{~nm}^{2}$, $A_{\text {mod-2(edge) }}=1.4 \mathrm{~nm}^{2}$, respectively (Figure 1).

Surface areas, occupied by a molecule in a closest packed monolayer will be $A_{\text {pack(face) }}=1.9 \mathrm{~nm}^{2}, A_{\text {pack(edge-1) }}=1.0 \mathrm{~nm}^{2}$ and $A_{\text {pacedge-2) }}=1.2 \mathrm{~nm}^{2}$ (Figure 2). The maximum error when defining characteristics of a layer is: $A_{m o l}$ and $D \pi-3 \%, c_{\text {face }}$ and y $-5 \%$, $D$ and $w_{\text {inter-M-i }}-7 \%, B, c_{i-\text { face }}, c_{\text {fface }}, c_{i-\text { edge }}, c_{\text {fedge }}, n, w_{\text {in-M }}$ and $d_{i}-10 \%$. 
a)<smiles>C1=CC(c2ccc(C(=C3C=CC(C(c4ccccc4)=c4ccc(=C(c5ccccc5)c5ccccc5)[nH]4)=N3)c3ccccc3)[nH]2)C=C1</smiles>

b)

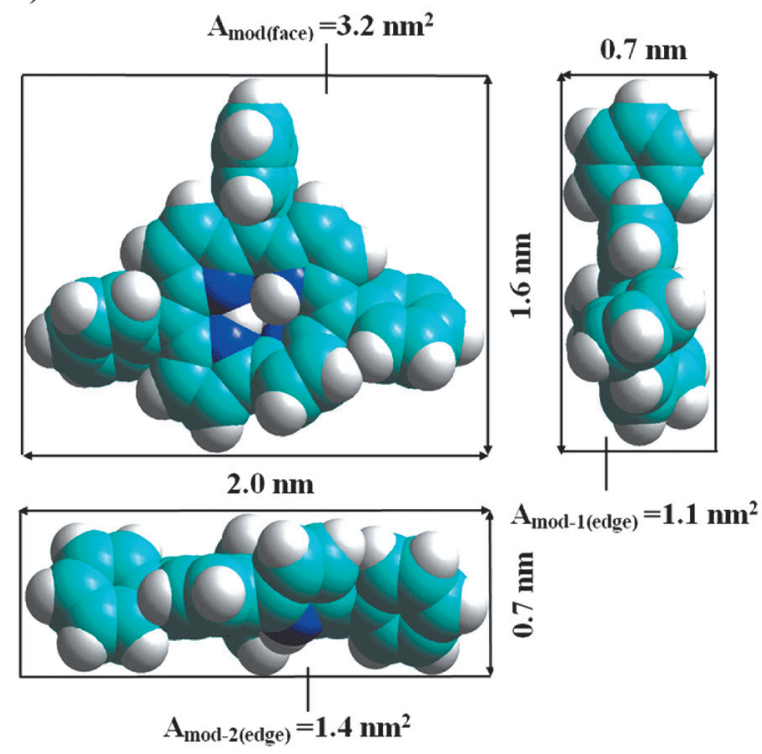

Figure 1. Structure (a) and model of $\mathrm{H}_{3} \mathrm{Ph}_{3}$ Cor molecule (b). $A_{\text {mod }}$ - the surface areas of circumscribed rectangles.

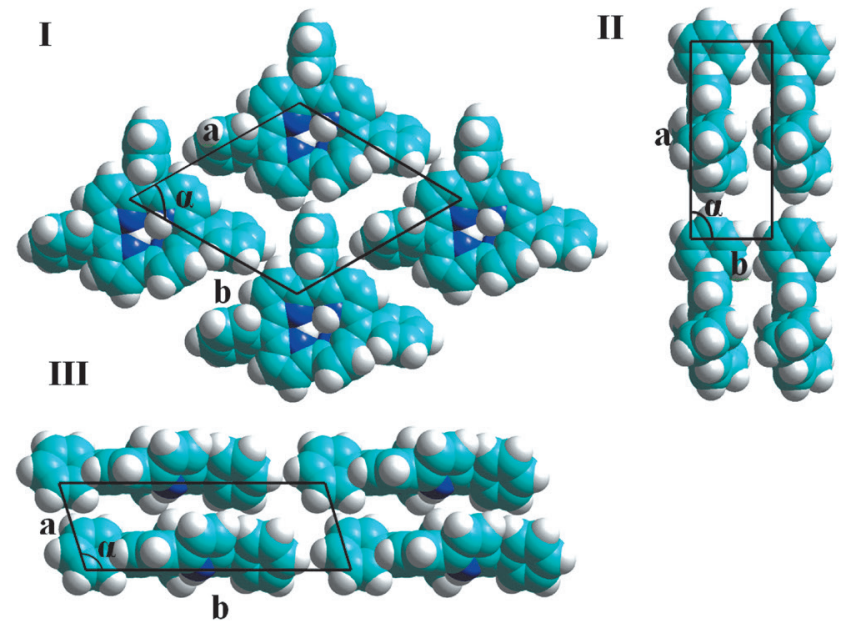

Figure 2. The scheme of face-on (I) and edge-on (II, III) closest packed molecules of $\mathrm{H}_{3}\left[(m s-\mathrm{Ph})_{3} \mathrm{Cor}\right]$. $A_{\text {packfface })}=1.9 \mathrm{~nm}^{2}\left(\mathrm{a}=1.5 \mathrm{~nm} ; \mathrm{b}=1.5 \mathrm{~nm} ; \alpha=60^{\circ}, \mathrm{I}\right)$, $A_{\text {packedge I })}=1.0 \mathrm{~nm}^{2}\left(\mathrm{a}=1.6 \mathrm{~nm} ; \mathrm{b}=0.6 \mathrm{~nm} ; \alpha=86^{\circ}, \mathrm{II}\right)$; $A_{\text {pack(edge_2) }}^{\text {pack(edge_l) }}=1.2 \mathrm{~nm}^{2}\left(\mathrm{a}=0.6 \mathrm{~nm} ; \mathrm{b}=2.0 \mathrm{~nm} ; \alpha=108^{\circ}\right.$, III $)$.

\section{Results and Discussion}

The quantitative analysis of compression isotherms plotted along $\pi-A$ and $\pi A-\pi$ axes (Figure 3 ) has shown that both stable monolayers and bilayers $\mathrm{H}_{3}\left[(m s-\mathrm{Ph})_{3}\right.$ Cor $]$ are formed on the water surface within the studied in 4-29\% range of initial coverage degrees $\left(c_{\text {face }}\right)$. The main results of compression isotherm analysis and characteristics of $\mathrm{H}_{3}\left[(m s-\mathrm{Ph})_{3}\right.$ Cor $]$ floating layers are shown in Table 1 . It is demonstrated that a corrole given the $C=6.9 \cdot 10^{-5} \mathrm{~mol} \cdot \mathrm{l}^{-1}$ concentration of the solution and the $\mathrm{v}=2.3 \mathrm{~cm}^{2} / \mathrm{min}$ layer compression speed forms stable monolayers in a narrow range of initial surface coverage degrees $-c_{\text {face }}$ from $4 \%$ to $22.5 \%$ (Figure 3 ). If the values are $c_{\text {face }}>22.5 \%$, bilayers are registered already at the lowest surface pressures. Corroles produce stable monolayers of different types: if $c_{\text {face }} \leq 13.5 \%$, they have the face-on position of molecules in nanoaggregates $\left(\mathrm{M}_{\text {face }}\right)$, if $19.5 \% \geq c_{\text {face }} \geq 13.9 \%$, they have the edge-on position $\left(\mathrm{M}_{\text {edge }}\right)$, and if $c_{\text {face }}=20 \%$, then dry nanoaggregates $\left(\mathrm{M}_{\chi}\right)$ are formed.

Monolayers with face-on position are characterized by a large aggregation number $(13<n<81)$ (Table 1$)$ and a high content of water in aquaaggregates (up to $70 \%$ of $A_{m o l}$ ) and between them (up to $1.6 \mathrm{~nm}^{2}$ per $\mathrm{H}_{3} \mathrm{Ph}_{3}$ Cor molecule). A monolayer has high compressibility (up to $750 \mathrm{~m} \cdot \mathrm{N}^{-1}$ ). If values of initial surface coverage degrees $\left(19.5 \% \geq c_{\text {face }} \geq 13.9 \%\right)$ are average, the low pressure regions form stable edge-on-monolayers, where the molecule's plane is positioned at an angle to the water surface. The minimum tilt $\left(\psi_{\text {min }}\right)$ of $\mathrm{H}_{3} \mathrm{Ph}_{3}$ Cor molecules in stacks varies from $38^{\circ}$ to $60^{\circ}$, with the number of molecules in $M_{\text {edge }}$-aggregates varying from 29 to 67 , the content of water between aggregates varying from 0.4 to $0.9 \mathrm{~nm}^{2}$ per molecule, and the layer compressibility being low (down to $430 \mathrm{~m} \cdot \mathrm{N}^{-1}$ ). A monolayer of dry edge-on $M \mathrm{c}$-aggregates is characterized by low layer compressibility, $B=380 \mathrm{~m} \cdot \mathrm{N}^{-1}$, the minimum number of molecules in aggregates $(n=17)$ and the maximum content of water between aggregates at the initial point of the stable monolayer state $\left(w_{\text {inter-M-i }}=2.5 \mathrm{~nm}^{2}\right)$. If the initial surface coverage degrees are high $\left(c_{\text {face }}=23.2 \%\right)$, the surface pressure of up to $0.4 \mathrm{mN} / \mathrm{m}$ forms a stable bilayer structure (3D-nanoaggregates with 79-151 molecules in them).

The obtained results can be used to construct a model of $\mathrm{H}_{3} \mathrm{Ph}_{3}$ Cor $M_{\text {face }}$ - and $M_{\text {edge }}$-floating monolayers formed from the solution in methylene chloride. For monolayers with $M_{\text {face }}$ - and $M_{\text {edge }}$-aggregates the analysis of dependencies of the surface area per nanoaggregate molecule on the initial surface coverage degree (Table 1, Figure 4a) results in the following correlations:

$$
\begin{aligned}
& A_{\text {mol }}=26 /\left(1+c_{\text {face }}\right)\left(\text { for } M_{\text {face }}-\text { aquaaggregates }\right) \\
& \left.A_{\text {mol }}=4.067-0.162 \cdot c_{\text {face }} \text { (for } M_{\text {edge }} \text {-aquaaggregates }\right)
\end{aligned}
$$


a)

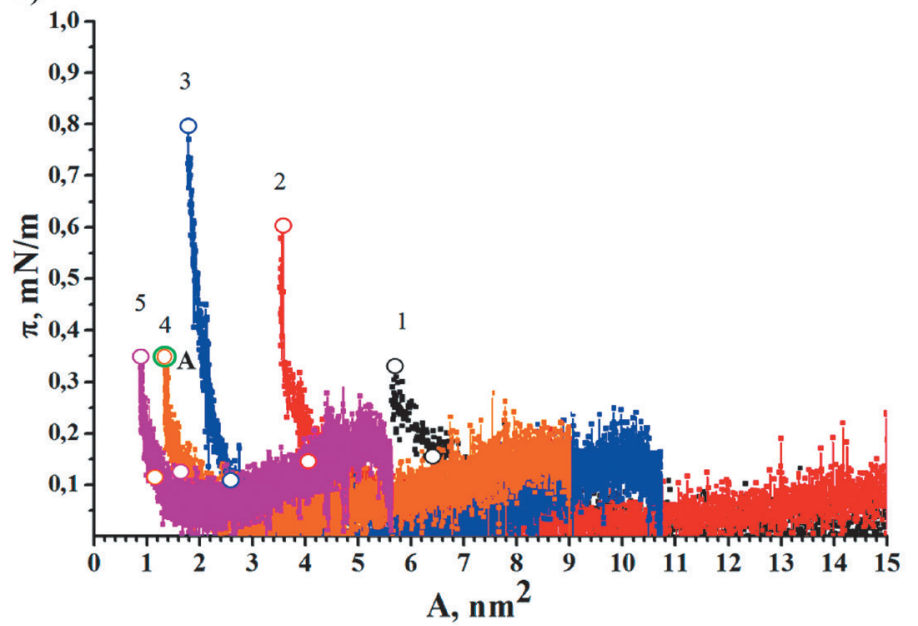

b)

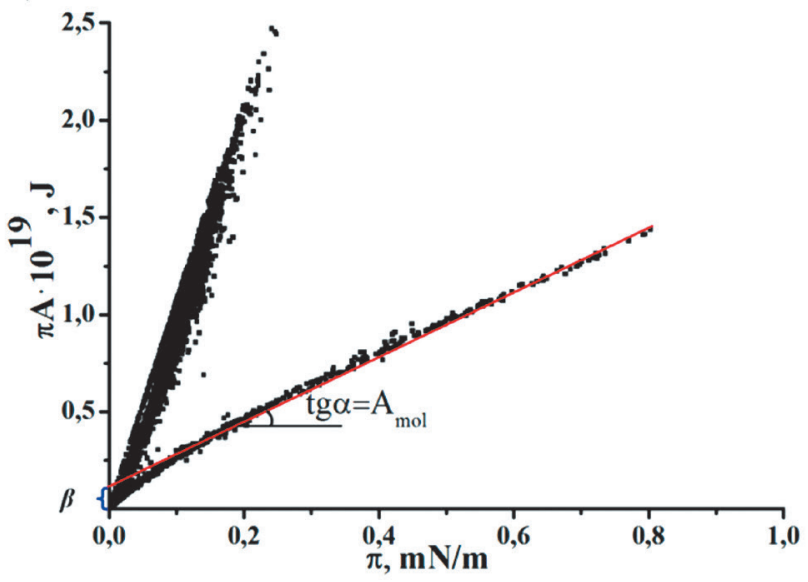

Figure 3. $\pi-A$ (a) isotherms of $\mathrm{H}_{3}\left[(\mathrm{~ms}-\mathrm{Ph})_{3} \mathrm{Cor}\right]$, obtained at $C=6.9 \cdot 10^{-5} \mathrm{~mol} / 1, \mathrm{v}=2.3 \mathrm{~cm}^{2} / \mathrm{min}$ and various initial surface coverage degrees: $c_{\text {face }}=4(1), 7(2), 15(3), 18(4), 29(5) \%$ and $\pi A-\pi(b)$ isotherm of $\mathrm{H}_{3}\left[(m s-\mathrm{Ph})_{3} \mathrm{Cor}\right]\left(c_{\text {face }}=15 \%\right)$. The floating $M$-monolayer was transferred onto a solid support by dips at $\pi_{\mathrm{tr}}=0.35 \mathrm{mN} / \mathrm{m}$ (point A on Figure $3 \mathrm{a}$ ).

Table 1. Characteristics of $\mathrm{H}_{3}\left[(\mathrm{~ms}-\mathrm{Ph})_{3} \mathrm{Cor}\right]$ floating layers, obtained at different initial surface coverage degrees.

\begin{tabular}{|c|c|c|c|c|c|c|c|c|c|c|c|c|c|}
\hline $\begin{array}{l}\mathrm{c}_{\text {face }} \\
(\%)\end{array}$ & $\begin{array}{c}\text { Nanoagregate- } \\
\text { type }\end{array}$ & $\begin{array}{c}c_{i \text {-face }}{ }^{-} \\
c_{\text {f-face }} \\
\left(\Delta c_{j \text {-face }}\right) \\
(\%)\end{array}$ & $\begin{array}{l}c_{i-a g g r} \\
(\%)\end{array}$ & $\begin{array}{c}(\Delta \pi) \\
\pi_{\mathrm{i}}-\pi_{\mathrm{f}} \\
(\mathrm{mN} / \mathrm{m})\end{array}$ & $\begin{array}{l}A_{m o l} \\
\left(\mathrm{~nm}^{2}\right)\end{array}$ & $\mathrm{n}$ & $\begin{array}{c}D_{a g g r} \\
\left(S_{a g g r}\right) \\
(\mathrm{nm}) \\
\left(\mathrm{nm}^{2}\right)\end{array}$ & $\underset{-\psi_{\max }\left({ }^{\circ}\right)}{\Psi_{\min }}$ & $\begin{array}{c}r \\
(\mathrm{~nm})\end{array}$ & $\begin{array}{c}w_{i n-M} / A_{m o l} \\
(\%)\end{array}$ & $\begin{array}{c}w_{\text {inter-M-i }} \\
(\mathrm{nm})^{2}\end{array}$ & $\begin{array}{c}d_{i} \\
(\mathrm{~nm})\end{array}$ & $\begin{array}{c}B \\
(\mathrm{~m} / \mathrm{N})\end{array}$ \\
\hline \multicolumn{14}{|c|}{$\mathrm{H}_{3} \mathrm{Ph}_{3} \mathrm{Cor}=6.9 \cdot 10^{-5} \mathrm{~mol} \cdot \mathrm{l}^{-1}$ (layer compression speed $\left.\mathrm{v}=2.3 \mathrm{~cm}^{2} / \mathrm{min}.\right)$} \\
\hline 4 & $M_{\text {face }}$ & $\begin{array}{c}24-28 \\
(4)\end{array}$ & 76 & $0.1-0.3$ & 5.2 & 13 & $\begin{array}{c}9 \\
(70)\end{array}$ & 0 & 1.1 & 69 & 1.6 & 1.3 & 750 \\
\hline 7 & $M_{\text {face }}$ & $\begin{array}{c}34-45 \\
(11)\end{array}$ & 69 & $0.1-0.6$ & 3.3 & 31 & $\begin{array}{c}11 \\
(100)\end{array}$ & 0 & 0.6 & 52 & 1.5 & 2.3 & 540 \\
\hline 8 & $M_{\text {face }}$ & $\begin{array}{c}43-58 \\
(15)\end{array}$ & 70 & $0.1-0.6$ & 2.6 & 45 & $\begin{array}{c}12 \\
(120)\end{array}$ & 0 & 0.4 & 38 & 1.1 & 2.3 & 500 \\
\hline 10 & $M_{\text {face }}$ & $\begin{array}{c}55-67 \\
(12)\end{array}$ & 77 & $0.1-0.5$ & 2.3 & 58 & $\begin{array}{c}13 \\
(130)\end{array}$ & 0 & 0.3 & 29 & 0.7 & 1.7 & 500 \\
\hline 13 & $M_{\text {face }}$ & $\begin{array}{c}62-81 \\
(19)\end{array}$ & 74 & $0.1-0.6$ & 1.9 & 81 & $\begin{array}{c}14 \\
(150)\end{array}$ & 0 & 0.1 & 16 & 0.6 & 2.3 & 450 \\
\hline 15 & $M_{\text {edge }}$ & $\begin{array}{c}32-45 \\
(13)\end{array}$ & 66 & $0.1-0.8$ & 1.6 & 29 & $\begin{array}{c}8 \\
(50)\end{array}$ & $38^{*}-90$ & - & 51 & 0.9 & 1.8 & 430 \\
\hline 17 & $M_{\text {edge }}$ & $\begin{array}{c}41-50 \\
(9)\end{array}$ & 67 & $0.1-0.5$ & 1.3 & 49 & $\begin{array}{c}9 \\
(60)\end{array}$ & $50 *-90$ & - & 38 & 0.6 & 2.0 & 430 \\
\hline 18 & $M_{\text {edge }}$ & $\begin{array}{l}52-58 \\
(6)\end{array}$ & 75 & $0.1-0.4$ & 1.2 & 67 & $\begin{array}{c}10 \\
(80)\end{array}$ & $60^{*}-90$ & - & 31 & 0.4 & 1.5 & 410 \\
\hline 20 & $M \chi$ & $\begin{array}{c}40-79 \\
(7)\end{array}$ & 83 & $0.1-1.4$ & 1.1 & 17 & $\begin{array}{c}5 \\
(20)\end{array}$ & 90 & - & 0 & 0.4 & 2.5 & 380 \\
\hline 25 & \multirow{2}{*}{ bilayer } & - & - & $0.2-0.4$ & 0.8 & 79 & - & - & - & - & - & 1.8 & 670 \\
\hline 29 & & - & - & $0.2-0.4$ & 0.8 & 151 & - & - & - & - & - & 1.8 & 550 \\
\hline
\end{tabular}

$c_{\text {face }}$ initial surface coverage degree; $c_{i \text {-face }}$ and $c_{\text {fface }}$ current surface coverage degrees at the initial and final points of the stable state, respectively; $\Delta c_{j-f a c e}$ state existence region with respect to the current surface coverage degree; $c_{i-\text { aggr }}$ the degree of surface coverage with $M$-aggregates at the initial point of the stable state; $\pi_{\mathrm{i}}-\pi_{\mathrm{f}}(\Delta \pi)$ pressure region, in which the stable state exists; $A_{\text {mol }}$ surface area per molecule in a nanoaggregate; $\mathrm{n}$ aggregation number; $D_{a g g r}$ and $S_{a g g r}$ the diameter and surface area of a nanoaggregate; $\psi_{\min }$ the minimum tilt of molecules in stacks ("dry" aggregates); $w_{i n-M}$ and $w_{\text {inter-M-i }}$ the content of water in $M$-aggregates and between them (per molecule) at the initial point of the stable state; $r$ the average distance between molecule in an aggregate; $d_{i}, d_{f}$ the distance between nanoaggregates at the initial and final points of the stable state; $B$ compressibility of the layer.

*The values of $A_{\text {proj-1(edge) }}=0.8 \mathrm{~nm}^{2}, A_{\text {pak-1(ldge) }}=1.0 \mathrm{~nm}^{2}$ were used in calculations. 
They can help to determine constants, characterizing the $\mathrm{H}_{3} \mathrm{Ph}_{3} \mathrm{Cor}$ floating layer: the maximum surface area per molecule in an edge-on-monolayer $\left(1.8 \mathrm{~nm}^{2}\right)$, and the maximum initial surface coverage values causing such faceon- and edge-on monolayers to be formed: $c_{\text {face }}=13.5 \%$ and $c_{\text {face }}=19.5 \%$, respectively. Analysis of dependence on the initial surface coverage degree with respect to other characteristics of a monolayer (Table 1, Figure 4b-d) resulted in the following correlations.

For $M_{\text {face }}$ monolayers:

$$
\begin{aligned}
& n=-24.8+8.1 \cdot c_{\text {face }} \\
& D_{\text {aggr }}=7.7+0.5 \cdot c_{\text {face }} \\
& w_{\text {in-M }} / A_{\text {mol }}=93.7-6.2 \cdot c_{\text {face }} \\
& c_{\text {i-face }}=4.7+4.6 \cdot c_{\text {face }} \\
& c_{\text {f-face }}=4.8+6.0 \cdot c_{\text {face }}
\end{aligned}
$$

and for $M_{\text {edge }}$ monolayers:

$$
\begin{aligned}
& n=-164.3+12.9 \cdot c_{\text {face }} \\
& D_{\text {aggr }}=-3,2+0.7 \cdot c_{\text {face }} \\
& w_{\text {in-M }} / A_{\text {mol }}=150.5-6.6 \cdot c_{\text {face }} \\
& c_{\text {ifface }}=-66.4+6.5 \cdot c_{\text {face }} \\
& c_{\text {fface }}=-19.7+4.3 \cdot c_{\text {face }}
\end{aligned}
$$

The results obtained make it possible to compile a passport ${ }^{[35]}$ of the floating layers of $\mathrm{H}_{3} \mathrm{Ph}_{3}$ Cor (Table 2). The schemes illustrating the fragment and main structural characteristics of monolayers with face-on $\left(c_{\text {face }}=4 \%\right)$ and edge-on aquaaggregates $\left(c_{\text {face }}=15 \%\right)$, and with dry nanoaggregates $\left(c_{\text {face }}=20 \%\right)$ are shown in Figure 5 .

LS-films of $\mathrm{H}_{3} \mathrm{Ph}_{3}$ Cor were formed from the floating monolayer produced on the water surface by using the horizontal lift method. Figure 6 shows UVVis spectra of $\mathrm{H}_{3} \mathrm{Ph}_{3}$ Cor solution in methylene chloride $\left(C=6.9 \cdot 10^{-5} \mathrm{~mol} \cdot \mathrm{l}^{-1}\right)$ and those of LS-films on a quartz substrate. The number of the substrate's immersions $(\mathrm{k})$ into the layer is from 1 to 77 . The comparison of the spectra shows a different degree of $\mathrm{H}_{3} \mathrm{Ph}_{3}$ Cor aggregation in the solution and the films. The Soret band of the spectrum of LangmuirSchaefer films $(\lambda=421 \mathrm{~nm})$ has a $6 \mathrm{~nm}$ red shift relative to the band in the spectrum of the solution $(\lambda=415 \mathrm{~nm})$. Such behaviour corresponds to formation of $J$-aggregates of corroles in the films.

\section{Conclusions}

Thus, the study shows the possibility of differently structured $\mathrm{H}_{3} \mathrm{Ph}_{3}$ Cor floating layers to be formed on a water surface: monolayers with $M_{\text {face }}$-aquaaggregates $\left(c_{\text {face }} \leq 13.5 \%\right)$, $M_{\text {edge }}$-aquaaggregates $\left(13.9 \% \leq c_{\text {face }} \leq 19.5 \%\right)$ and $M_{\text {edge }}$-dry aggregates $\left(20.0 \% \leq c_{\text {face }} \leq 22.5 \%\right)$ and polylayers with 3D nanoaggregates $\left(c_{\text {face }} \geq 23.2 \%\right)$. Main characteristics of the structure and the properties of $M$-monolayers were determined (the size of $M$-nanoaggregates, formed within a layer, the number of molecules in them, the distance between the a)

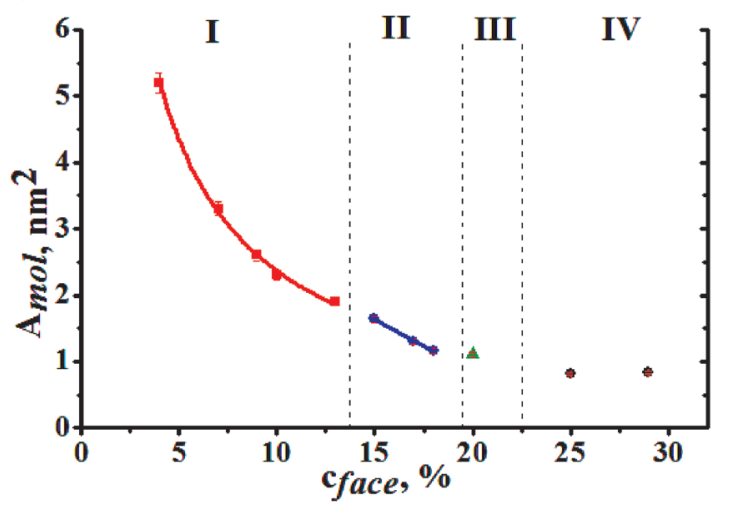

c)

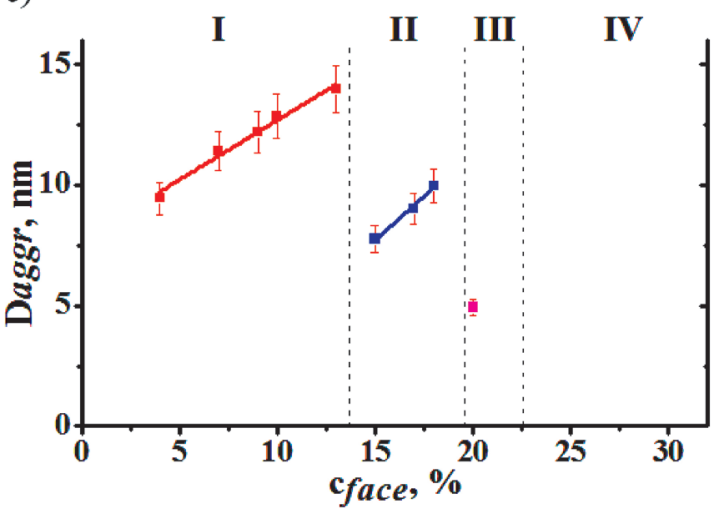

b)

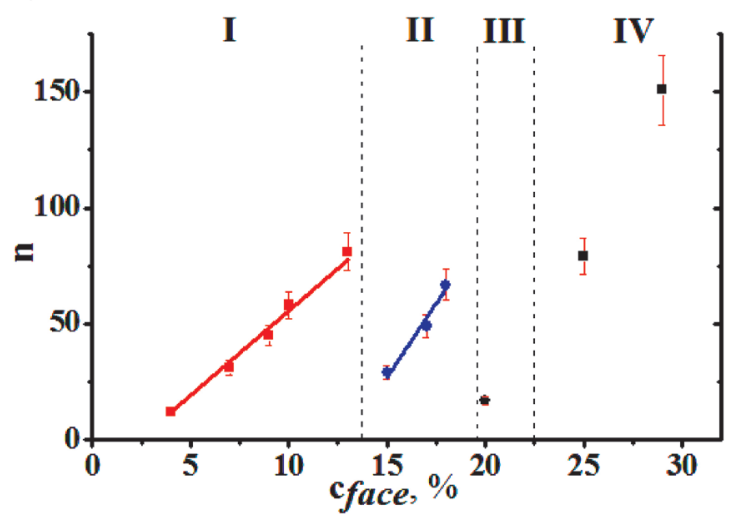

d)

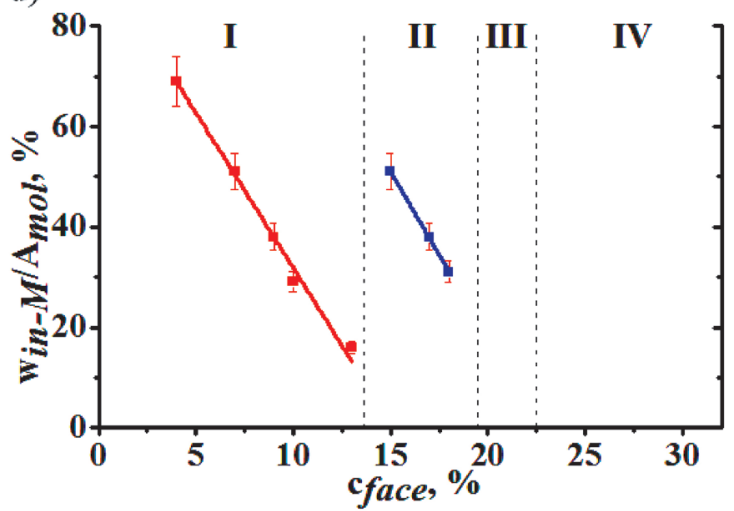

Figure 4. Dependencies of the surface area per molecule in $M$-aggregate $\left(A_{m o l}, \mathrm{a}\right)$, the aggregation number $(n, \mathrm{~b})$, the diameter of $M$-nanoaggregates $\left(D_{a g g r}, \mathrm{c}\right)$ and the content of water in nanoaggregates $\left(w_{i n-M} / A_{m o l}, \mathrm{~d}\right)$ on the initial surface coverage degree. I - monolayers (face-on); II - monolayers (edge-on); III - monolayers (edge-dry); IV - bilayers. 
Table 2. Passport of the floating layers of $\mathrm{H}_{3} \mathrm{Ph}_{3}$ Cor.

\begin{tabular}{|c|c|c|c|c|}
\hline $\begin{array}{l}\text { Nanoaggregate } \\
\text { type }\end{array}$ & $\begin{array}{l}\text { Molecular } \\
\text { orientation in } \\
M \text {-aggregate }\end{array}$ & $\begin{array}{l}\text { Formation conditions } \\
\text { (from the model) }\end{array}$ & $\begin{array}{c}\text { Dependences } \\
\text { of characteristics } \\
\text { of a monolayer on } \mathrm{c}_{\text {face }} \\
\text { (model) }\end{array}$ & Constants \\
\hline \multicolumn{5}{|c|}{$C=6.9 \cdot 10^{-5} \mathrm{~mol} \cdot 1^{-1} ; \mathrm{v}=2.3 \mathrm{~cm}^{2} \cdot \mathrm{min}^{-1} ; \mathrm{t}=20 \pm 1^{\circ} \mathrm{C}$} \\
\hline $2 \mathrm{D}, M_{\text {face-aqua }}$ & $\begin{array}{l}\text { face-on } \\
\text { (in-plane) }\end{array}$ & $c_{\text {face }} \leq 13.5 \%$ & $\begin{array}{c}n=-24.8+8.1 \cdot c_{\text {face }} \\
D_{\text {aggr }}=7.7+0.5 \cdot c_{\text {face }} \\
w_{\text {in-M }} / A_{\text {mol }}=93.7-6.2 \cdot c_{\text {face }} \\
c_{\text {i-face }}=4.7+4.6 \cdot c_{\text {face }} \\
c_{\text {fface }}=4.8+6.0 \cdot c_{\text {face }}\end{array}$ & $\begin{array}{c}n^{\max }=85 \\
\left(D_{\text {aggr }}\right)^{\max }=14.5 \mathrm{~nm} \\
\left.w_{\text {in-M }}\right)^{A_{\text {mol }}}=10 \% \\
c_{i-a g g r}=\text { const }=73 \% \\
\left(c_{i-f a c e}\right)^{\max }=67 \% \\
\left(c_{f-f a c e}\right)^{\max }=86 \%\end{array}$ \\
\hline $2 \mathrm{D}, M_{\text {edge-aqua }}$ & edge-on & $13.9 \leq c_{\text {face }} \leq 19.5 \%$ & $\begin{array}{c}n=-164.3+12.9 \cdot c_{\text {face }} \\
D_{\text {aggr }}=-3.2+0.7 \cdot c_{\text {face }} \\
w_{i n-M} / A_{\text {mol }}=162.4-8.2 \cdot c_{\text {face }} \\
c_{\text {iface }}=66.4+6.5 \cdot c_{\text {face }} \\
c_{\text {fface }}=-19.7+4.3 \cdot c_{\text {face }}\end{array}$ & 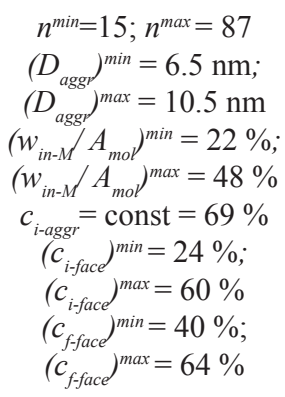 \\
\hline $2 \mathrm{D}, \mathrm{dry}, M_{\mathrm{c}}$ & edge-on & $20.0 \leq c_{\text {face }} \leq 22.5 \%$ & & \\
\hline $3 \mathrm{D}$ & - & $c_{\text {face }} \geq 23.2 \%$ & & \\
\hline
\end{tabular}

aggregates, the content of water in the aggregates and between them, compressibility, the existence region with respect to the pressure and the running surface concentration). Dependencies of the main parameters of monolayers with $M_{\text {face }}$ and $M_{\text {edge }}$-aggregates on the initial surface coverage degree were determined. A quantitative model of $\mathrm{H}_{3} \mathrm{Ph}_{3} \mathrm{Cor}$ monolayers, formed from a solution in methylene chloride, was constructed. A distinctive feature of triphenylcorrole floating face-on monolayers is the formation of the dry $M$ nanoaggregates. Conditions for 3D nanoaggregate formation in $\mathrm{H}_{3} \mathrm{Ph}_{3}$ Cor floating layers and the number of molecules in them were determined. The results obtained make it possible to compile a passport of the floating layers of $\mathrm{H}_{3} \mathrm{Ph}_{3}$ Cor. Langmuir-Shaeffer films were formed from a stable floating monolayer, produced on a water surface. Comparison of the spectra of the solution and the films indicates the formation of $J$-aggregates of $\mathrm{H}_{3} \mathrm{Ph}_{3}$ Cor in films.

Acknowledgements. This work was partially supported by the Russian Foundation for Basic Research (Project N 15-4203211a) and Ministry of Education and Science of Russian Federation (State task for ISUCT). a)

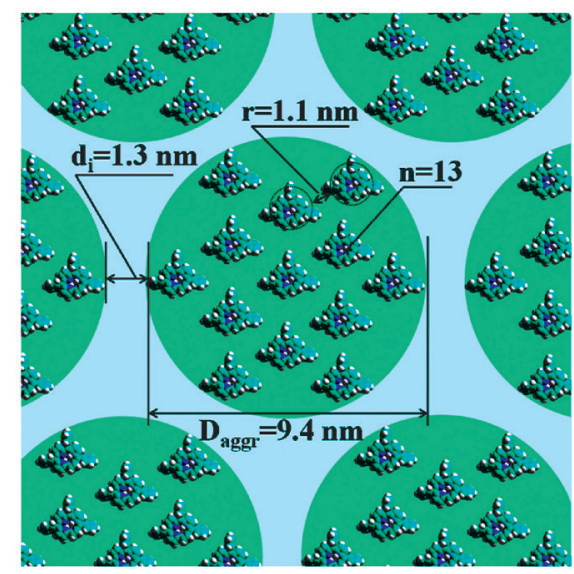

b)

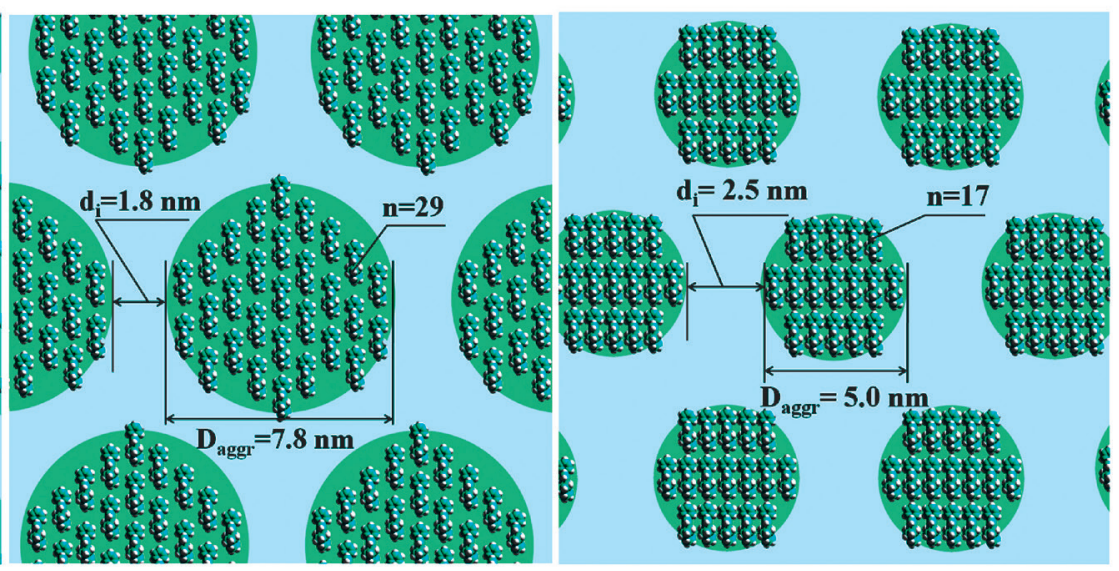

Figure 5. Schemes, illustrating fragments of the structure and main structural characteristics of triphenylcorrole monolayers with face-on (a, $c_{\text {face }}=4 \%$ ) and edge-on ( $\mathrm{b}, c_{\text {face }}=15 \%$ ) aquaaggregates, and also dry edge-on (c, $c_{\text {face }}=20 \%$ ) nanoaggregates. 


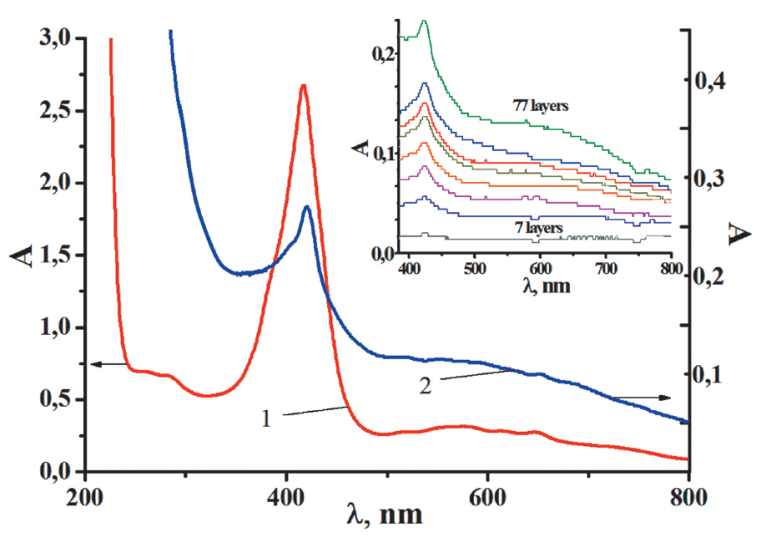

Figure 6. Absorption spectra of the $\mathrm{H}_{3} \mathrm{Ph}_{3} \mathrm{Cor}\left(C=3.6 \cdot 10^{-5} \mathrm{~mol} / \mathrm{l}\right)$ solution in $\mathrm{CH}_{2} \mathrm{Cl}_{2}$ (1) and its Langmuir-Schaefer films (77 edge-on monolayers, 2). Inset: absorption spectra of LS-films (7, 28, 35, 42, 49, 63, 70 and 77 edge-on monolayers).

\section{References}

1. Aviv I., Gross Z. Chem. Commun. 2007, 1987-1999.

2. Hwang J.Y., Lubow J., Chu D., Ma J., Agadjanian H., Sims J., Gray H.B., Gross Z., Farkas D.L., Medina-Kauwe L.K. Mol. Pharm. 2011, 8, 2233-2243.

3. Berezina N.M., Vu T.T., Karimov D.R., Kumeev R.S., Kustov A.V., Bazanov M.I., Berezin D.B. Russ. J. Gen. Chem. 2014, 84, 737-744.

4. Liua H.-Y., Mahmooda M.H., Qiuc S.-X., Chang C.K. Coord. Chem. Rev. 2013, 257, 1306-1333.

5. Thomas K., Alemayehu A.B., Conradie J., Beavers C.M., Ghosh A. Acc. Chem. Res. 2012, 45, 1203-1214.

6. Aviv-Harel I., Gross Z. Coord. Chem. Rev. 2011, 255, 717736.

7. Paolo S., Anna A., Mariachiara P., Giuseppe V., Kolanu S.L.G., Yarasi S., Filippo D.A. Computat. Theoret. Chem. 2014, 1030, 59-66.

8. Koifman O.I., Nikitina G.E., Berezin B.D. Zh. Fiz. Khim. 1982, 56, 737 (in Russ.).

9. Ivanova Y.B., Savva V.A., Mamardashvili N.Z., Starukhin A.S., Ngo T.H., Dehaen W., Maes W., Kruk M.M. J. Phys. Chem. A 2012, 116, 10683.

10. Zou H., Wang H., Mei G., Liu H., Chang C-K. Prog. Chem. 2015, 27, 666-674.

11. Valkova L.A., Betrencourt C., Hochapfel A., Myagkov I.V., Feigin L.A. Mol. Cryst. Liq. Cryst. 1996, 287, 269.
12. Valkova L., Borovkov N., Koifman O., Kutepov A., Berzina T., Fontana M., Rella R., Valli L. Biosensors Bioelectronics 2004, 20, 1177

13. Valkova L., Borovkov N., Maccioni E. et al. Colloids Surf., A 2002, 198-200, 891.

14. Paolesse R., Di Natale C., Macagnano A., Sagone F., Scarselli M.A., Chiaradia P., Troitsky V.I., Berzina T.S., D’Amico A. Langmuir 1999, 15, 1268-1274.

15. Bursa B., Wróbel D., Lewandowska K., Graja A., Grzybowski M., Gryko D.T. Synthetic Metals 2013, 176, 18-25.

16. Valkova L., Borovkov N., Kopranenkov V., Pisani M., Bossi M., Rustichelli F. Mater. Sci. Eng., C 2002, 22, 167.

17. Valkova L., Borovkov N., Pisani M., Rustichelli F. Thin Solid Films 2001, 401, 267.

18. Valkova L.A., Valli L., Casilli S., et al. Langmuir 2008, 24, 4857-4864.

19. Tebi S., Aldahhak H., Serrano G., Schöfberger W., Rauls E., Schmidt W.G., Koch R., Müllegger S. Nanotechnology 2016 , 27, 025704.

20. Sinha W., Kumar M., Garai A., Purohit C.S., Som T., Kar S. Dalton Trans. 2014, 43, 12564.

21. Maiorova L.A. Synopsis of D.Sc. (Phys-Math.) Thesis, Ivanovo, 2012. 32 p. (in Russ.).

22. Valkova L., Menelle A., Borovkov N., et al. J. Appl. Crystallogr. 2003, 36, 758.

23. Valkova L., Borovkov N., Pisani M., Rustichelli F. Langmuir 2001, 17, 3639.

24. Valkova L.A., Shabyshev L.S., Borovkov N.Y., Feigin L.A., Rustichelli F. J. Inclusion Phenom. Macrocyclic Chem. 1999, $35,243$.

25. Valkova L.A., Shabyshev L.S., Feigin L.A., Akopova O.B. Molecular Materials 1996, 6, 291.

26. Maiorova-Valkova L.A., Koifman O.I., Burmistrov V.A. et. al. Protec. Metals Phys. Chem. Surf. 2015, 51, 85.

27. KarlyukM.V., Krygin Y.Y., Maiorova-Valkova L.A.,Ageeva T.A., Koifman O.I. Russ. Chem. Bull. 2013, 62, 471.

28. Valkova L.A., Glibin A.S., Koifman O.I. Macroheterocycles 2011, 4, 3, 222-226.

29. Valkova L.A., Glibin A.S., Koifman O.I., Erokhin V.V. J. Porphyrins Phthalocyanines 2011, 15, 1044.

30. Petrova M.V., Maiorova L.A., Gromova O.A., Bulkina T.A., Ageeva T.A., Koifman O.I. Macroheterocycles 2014, 7, 267.

31. Semeikin A.S., Koifman O.I., Berezin B.D. Chem. Heterocycl. Compd. 1986, 22, 629.

32. Zelentsov V.V., Stroesku A.K., Koroleva T.A., Koifman O.I. Koord. Khim. 1983, 9, 168 (in Russ.).

33. Valkova L.A., Glibin A.S., Valli L. Colloid J. 2008, 70, 6.

34. Valkova L., Zyablov S., Erokhin V., Koifman O. J. Porphyrins Phthalocyanines 2010, 14, 513.

35. Maiorova L.A. D.Sc. (Phys-Math.) Thesis, Ivanovo, 2012. 382 p. (in Russ.). 